\title{
POPHISTORIA, POPPOLITYKA I POLITROZRYWKA W KSZTALCENIU HUMANISTYCZNYM CUDZOZIEMCÓW
}

\author{
Słowa kluczowe: kulturoznawstwo glottodydaktyczne, politologia, polszczyzna polityczna
}

Streszczenie. Ucząc języka polskiego i wiedzy o Polsce cudzoziemców, staramy się przygotować studentów do w miarę komfortowego życia w kulturze docelowej. Wyjaśniamy m.in. wiele kwestii historycznych i politycznych, budujących naszą tożsamość narodową. Funkcjonują one w polskim dyskursie jako szereg mitów, wyobrażeń, obudowanych znaczeniami, interpretacjami, są uporządkowane w konkretne paradygmaty kultury. Ulegają wpływom kultury popularnej, co znacznie potęguje ich oddziaływanie. W niniejszym tekście zostanie przedstawiony szereg przemyśleń doświadczonego nauczyciela, budującego markę Polski, uczącego nt. polskiej racji stanu, wprowadzającego na lektoratach zagadnienia historyczne, politologiczne, w popkulturowym kontekście.

Kiedy kilka lat temu po raz ostatni zastanawiałem się nad miejscem wiedzy o polityce w glottodydaktyce polonistycznej (Kajak 2010), oczywiście narzekałem, że brakuje podręczników do nauczania w tym zakresie, choć z drugiej strony stwierdzałem, że ów brak nie oznacza, iż na lektoratach języka polskiego dla cudzoziemców nie mówi się o polityce, nie dyskutuje o tego typu sprawach. Przypominałem, że zainteresowanie rzeczywistością polityczną to przecież część składowa zainteresowania szeroko pojmowaną kulturą polską, więc pewne treści politologiczne znajdują się w większości istniejących materiałów do nauki polszczyzny. Na tej podstawie, w zależności od potrzeb i sytuacji, nauczyciele mogą dostarczać słuchaczom kolejne warstwy potrzebnych informacji.

Każdy doświadczony glottodydaktyk wie, że brak podręczników do nauki jakiegoś języka specjalistycznego nie znaczy, iż tej odmiany języka się nie uczy bądź też nie informuje się studentów o konkretnych sprawach z tym obszarem związanych. Świadczy o tym m.in. fakt, że na polskich uczelniach wyższych

*p.kajak@uw.edu.pl, Centrum Języka Polskiego i Kultury Polskiej dla Cudzoziemców POLONICUM, Wydział Polonistyki, Uniwersytet Warszawski, 00-927 Warszawa, ul. Krakowskie Przedmieście 26/28. 
prowadzi się (bardzo dobre!) kursy przygotowujące do studiów także na kierunkach politologicznych (czy szerzej: społecznych). Nauczyciele korzystają z własnych materiałów dydaktycznych, dzięki którym studenci z sukcesem podejmują naukę na wybranych przez siebie kierunkach. Oczywiście, przygotowanie politologiczne prowadzących zajęcia jest różne. W przypadku Uniwersytetu Warszawskiego postanowiono, że właściwe zajęcia specjalistyczne w zakresie polszczyzny politycznej poprowadzi w II semestrze pracownik Wydziału Nauk Politycznych i Studiów Międzynarodowych. Jego praca wspomagana jest przez lektorów jpjo, wplatających do swoich zajęć z języka ogólnego już od I semestru wybrane zagadnienia poszerzające znajomość leksyki oraz pozwalające pełniej odnosić się do interesujących nas spraw, w tym tych aktualnych, wymagających natychmiastowej reakcji i komentarza. Dzięki takiemu połączeniu uzyskano bardzo sensowną, jak się wydaje, ,mieszankę” wiedzy o języku, o rzeczywistości politycznej/politologicznej oraz, co niezwykle istotne, o specyfice uczenia się w konkretnej jednostce UW.

Jak się zdaje, ów brak podręczników i, w zasadzie, prymat materiałów dydaktycznych przygotowywanych ad hoc, w przypadku polonistycznym wyszedł naszej dyscyplinie na dobre. Polski pejzaż polityczny zmienia się bowiem tak szybko i drastycznie, że większość publikacji wydrukowanych zdezaktualizowałaby się w zasadzie już kilkanaście miesięcy po ukazaniu się. I nie chodzi tu o zmiany osobowe dotykające najwyższych stanowisk w państwie (te są czymś normalnym w demokracji), a raczej te wynikające z przemian wpływających na tożsamość (tożsamości) rodaków, którym przyszło żyć w epoce kryzysu wielkich narracji, na dodatek w społeczeństwie dotkniętym traumą wielkiej zmiany (Sztompka 2000).

Mnogość tożsamości danej jednostki oraz kłopoty związane z wyborem, ustalaniem, odkrywaniem etc. tejże opisywało wielu badaczy na całym świecie. Nie jest moim celem przypominanie tej dyskusji oraz wszystkich wniosków z niej płynących. Przyjmę za Anthonym Giddensem, iż współcześnie tożsamość to ciągle podejmowany trud samookreślenia się w sytuacji, kiedy ludzkiemu losowi towarzyszy niepewność, ryzyko i wielość wyborów. Wieloaspektowość społecznej tożsamości ,ja" nie oznacza - o czym przekonująco pisze Przemysław Czapliński (2009, s. 353), że ta wielość prowadzi do jedności. Poszczególne aspekty tożsamości (np. narodowość, płeć, seksualność) nie muszą być spójne.

$\mathrm{W}$ innym miejscu i czasie zmagania z tożsamością, z łączeniem, sklejaniem, sztukowaniem poszczególnych jej aspektów, byłyby ciekawym studium egzystencji współczesnej jednostki. W przypadku polskim pojawia się jednak dojmujące poczucie chaosu w konstruowaniu XXI-wiecznej tożsamości w społeczeństwie, które - jak zauważa Przemysław Czapliński - ,gwałtownie poszukuje narracji pomagającej integrować rozproszone składniki doświadczenia historycznego" (2009, s. 104). 
W momencie upadku komunizmu zniknęła ,podstawowa zdobycz życia powojennego - jednolitość”, którą zawdzięczaliśmy wojnie ${ }^{1}$. To wojna właśnie „wytworzyła w społeczeństwie zgodę na elementarne wymogi industrialnej fazy modernizacji: porzucenie solidarności sąsiedzkiej charakterystycznej dla małej ojczyzny, powierzenie państwu planu życia zawodowego, zachowanie zdyscyplinowanej jedności”. To wojna ,przekazała Kościołowi i komunistom społeczeństwo, które po traumatycznym osiągnięciu identyczności wyznaniowej oraz etnicznej było przygotowane do życia w schizofrenicznym świecie katolicyzmu i komunistycznego egalitaryzmu" (Czapliński 2009, s. 102-103).

Upływu lat nie przetrwała także inna wielka narracja: emancypacyjna narracja solidarnościowa. Do jej zagubienia, jak się zdaje, musiało dojść, bo została ona zrodzona w wyniku działań legendotwórczych, nieuwzględniających pewnych zjawisk, postaw, grup. P. Czapliński zauważa, że „wspólna historia przesunęła je na margines; nadano im status uboczny lub wykluczono je - nie dlatego, że były mniej ważne, ale dlatego, że nie dawały się dopasować do wersji jednolicie antykomunistycznej, powszechnej i wysokiej" (Czapliński 2009, s. 216$)^{2}$.

Dzieli Polaków oraz zakłóca odnalezienie wspólnych tożsamościowych mianowników przekonanie o tym, co stało za Przełomem: czy opcja „,modernizacyjna", czy „tradycjonalistyczna"’3. W gorącym sporze obie strony sięgają po stereo-

${ }^{1}$ Pojawienie się nowych narracji $\mathrm{w}$ latach dziewięćdziesiątych zaburzyło - zdaniem P. Czaplińskiego - możliwość ,reprodukcji tego wzorca jedności i spowodowało, że stanęliśmy w obliczu zupełnie innej opowieści założycielskiej o powojennym społeczeństwie polskim. W miejsce narracji o zbiorowości, która powojenną spoistość zawdzięczała solidarności czasów wojny i okupacji, weszła przerażająca narracja o społeczności, która osiągnęła jedność etniczną i religijną w wyniku niemieckiej zbrodni ludobójstwa, sowieckiego zaboru Kresów, lecz także w wyniku niesolidarnych zachowań zbiorowych" - procesy zapoczątkowane w czasie okupacji i dokończone w okresie PRL-u (2009, s. 100).

${ }^{2}$ Przywoływany autor wymienia np. następujące ,zagubione ogniwa”: 1) zbiorowy udział kobiet w „S” (dziś wydaje się, że byli tam tylko mężczyźni. Por. Shana Penn, Podziemie kobiet, Warszawa 2003; Agnieszka Graff, Świat bez kobiet, Warszawa 2003 - w tym: Patriarchat po Seksmisji); 2) doświadczenia „demokracji ulicznej” i masowe upolitycznienie (Czapliński 2009, s. 216).

3 „Jeśli bowiem ktoś twierdzi, że Polska w 1989 roku odzyskała niepodległość dzięki zbiorowym pragnieniom wolności, kapitalizmu, Europy i tolerancji, wówczas będzie on uważał, że odtąd każdy powinien swoje życie projektować - i opowiadać samodzielnie (...). I na odwrót: jeśli ktoś uważa, że odzyskaliśmy wolność dzięki katolicyzmowi, dzięki walce o państwo bardziej polskie niż PRL i dzięki silnej więzi społecznej, wówczas wartości te zyskują mocniejsze prawo obywatelstwa, a opowieść o nich nabiera charakteru wielkiej narracji. Tymczasem po roku 1989 zdecydowana dominacja w sferze publicznej - a więc polu walki o znaczenie wspólnych symboli, o prawo dysponowania nimi i włączania ich w nowe konfiguracje, o społeczny prestiż i szacunek - przypadła orientacji, którą można nazwać „modernizacyjną” (...). Nie byłoby w tym nic złego, gdyby nie polityka symboliczna przez tę stronę stosowana. Mówiła ona bowiem wyobrażonym tradycjonalistom mniej więcej tyle: „Wasz patriotyzm wspiera się na nacjonalizmie, a zakrytym fundamentem tego nacjonalizmu jest nienawiść wobec obcych; wasza religijność jest obrzędowa, płytka, nieoświecona, a jej mrocznym podłożem jest mentalność ofiarnicza; wasza kompetencja polityczna jest niewielka, 
typy. Poszukują odmieńców, których dalej będzie się dało przeobrazić w obcych ${ }^{4}$, w opozycji do których będzie można określić własne odcienie „naszości”, „swojskości”.

Za głębokimi przeobrażeniami współczesnej kultury nie nadąża większość naszych polityków, nie nadążają także instytucje państwowe oraz Kościół. Wszyscy wymienieni zdają się lekceważyć to, co zrobiło z nami zniesienie barier komunikacyjnych (i tych wynikających z odległości w podróży, i tych związanych z dostępem do kanałów wymiany myśli i opinii) oraz dopuszczenie do uczestnictwa we współczesnej, antropologicznie postrzeganej, kulturze. Nie czas tu i miejsce, by snuć rozważania na temat kultury uczestnictwa w wieloplemiennym świecie konwergujących mediów. Warto natomiast, zwłaszcza edukując słuchaczy cudzoziemskich, wypowiedzieć kilka uwag na temat zderzenia nowoczesności (pozbawionej prefiksu czy też oznaczenia wartościującego) z paradygmatami polskiej kultury, m.in.: sarmatyzmem, romantyzmem, katolicyzmem, patriotyzmem czy kosmopolityzmem. Paradygmaty te, porządkujące dzieje Polski, uzmysławiające ciągłość pewnych sporów i tradycji, trzeba konfrontować ze współczesnymi ujęciami metodologicznymi humanistyki. Najpopularniejsze z nich wymieniała już przed laty Elwira Grossman (2010), m.in.: studia postkolonialne, studia genderowe oraz queer studies, studia o tożsamości, studia o performatywności, studia o pamięci, ekokrytyka (w tym ekofeminizm).

Tego typu działania, pozwalające zastosować nowoczesne humanistyczne trendy i inspiracje w odniesieniu do polskości i jej składowych, dają szansę na uzmysłowienie naszym podopiecznym, jak skomplikowane jest życie społeczeństwa doświadczonego w ostatnich wiekach tyloma katastrofami dziejowymi. Umożliwiają uzmysłowienie młodym humanistom, jak istotne jest krytyczne podejście do analizowanych zjawisk i postaw. I jak ważne jest poznanie polszczyzny politycznej. Wielu znakomitych badaczy (m.in. Jerzy Bralczyk i Elżbieta Sękowska) opisywało ją wychodząc z założenia, że politycy mogą „użyć słów i połączeń frazeologicznych ze wszystkich rejestrów języka, a w szukaniu popularności z jednej strony czy w nagłaśnianej przez media niezręczności z drugiej wpadać muszą na sformułowania oryginalne (...). Ale w świadomości użytkowników języka istnieje poczucie specyficzności mówienia o polityce i w polityce. I specyficzności funkcjonowania politycznych pojęć, terminów i nazw" (Bralczyk 2009, s. 5-6).

wasza znajomość reguł modernizacji - żadna, a wasze umiejętności rynkowe - żałosne" (Czapliński 2009, s. 244-245).

${ }^{4} \mathrm{Wg}$ P. Czaplińskiego od 200 lat (tj. od kiedy trwa spotkanie kultury polskiej z nowoczesnością) polskie imaginarium wytwarza niemal identyczne fantazmaty obcych. Matryca wytwarzająca obcych składa się z tych samych parametrów: nacjonalistycznego; patriotycznego (czy współpracowałeś?); tradycjonalistycznego (czy uznajesz wyższość tradycji nad zmianą?); płciowego; religijno-obyczajowego (2009, s. 104). 
Jeśli zgodzimy się z wielokrotnie wypowiadanym przez J. Bralczyka stwierdzeniem, że polityk istnieje przez język, musimy za kluczowe uznać ujęcie lingwakulturowe. Dla glottodydaktyka niezwykle interesująca (i potrzebna) będzie przede wszystkim warstwa leksykalna, mechanizmy leksykalne tej właśnie odmiany specjalistycznej. Słuchaczom przydadzą się specyficzne dla naszej kultury definicje, rozumienia słów, zdań oraz konteksty (historyczne, społeczne, obyczajowe), w których doszło do ich powstania. W nich zakodowane są stosunek i emocje Polaków do/wobec poszczególnych spraw, ale także dziedzictwo kultury lokalnej i pewna tradycja - przede wszystkim polityczna.

Niezwykle ciekawym przewodnikiem będzie tutaj Rafała Zimnego i Pawła Nowaka Stownik polszczyzny politycznej po roku 1989 (2009), zawierający nie tylko hasła przedmiotowe (materiałowe) - rejestrację i analizę najciekawszych językowych symboli politycznych, najbardziej zapadających w pamięć, które na stałe przeniknęły do polszczyzny ogólnej, ale i 26 haseł problemowych, informujących o najistotniejszych mechanizmach językowych i językowo-kulturowych, używanych przez polityków.

Pracę R. Zimnego i P. Nowaka można potraktować jako kolekcję skrzydlatych słów i fraz, kultowych tekstów, punchline'ów - czyli wszystkiego tego, co wpisuje się w postrzeganie kultury i jej kanonu (kanonów) jako zbioru fragmentów (a nawet fragmentów w wersji instant), budujących słownik żyjących współcześnie rodaków na takich samych prawach, co kultowe teksty z filmów, seriali, reklam etc. Nic więc dziwnego, że autorów-polityków zaczęto traktować jak regularnych celebrytów. Czas, w którym do tego doszło, świetnie opisuje Tomasz Olczyk w książce Politrozrywka i popperswazja. Reklama telewizyjna w polskich kampaniach wyborczych XXI wieku (2009). Autor ten przyjrzał się wyborom i kampaniom przedwyborczym z roku 2004 (do Parlamentu Europejskiego), z 2005 (wybory parlamentarne i prezydenckie), a także zweryfikował swoje tezy przy pomocy tego, co działo się w 2007 (wybory parlamentarne). Szczególnie interesowały go zmiany, które nastąpiły na skutek wkroczenia rzeczywistości rekla$\mathrm{my}^{5} \mathrm{w}$ dziedzinę polityki. Wojciech J. Burszta zauważył, że w tego typu sytuacji to polityka musi się przystosować do dyktowanych realiów, nigdy odwrotnie. Tak rodzą się ,politrozrywka i popperswazja. To zupełnie nowa sytuacja, wymuszająca zasadniczą rewizję podejścia do skuteczności przekazu, przenosząc politykę w sferę wirtualnej konstrukcji preferowanych obrazów świata” (2009, s. 16).

T. Olczyk w bardzo ciekawy sposób opisał mediatyzację polityki (i wszelkich aspektów jej rzeczywistości), jej spektakularyzację, urozrywkowienie. Nastąpiło to, oczywiście, na skutek wpływu mediów, o których mówi się rozmaicie: że albo kolonizują politykę, albo że transformują czy konstruują. Przy czym przywoływany badacz skupił się w swojej pracy na mediach „tradycyjnych” (głów-

${ }^{5}$ Reklamy już w jej nowoczesnej postaci, w której reklamom nadaje się wartości rozrywkowe za pośrednictwem wideoklipowej techniki komunikowania. 
nie telewizji, choć w kontekście 2007 roku wspomniał o youtubizacji polityki). Włączenie do badań nowszych kampanii i sprawdzenie działania tzw. mediów społecznościowych na pewno przeniosłyby wnioski autora w nowe, interesujące przestrzenie analizy.

Nie zmienia to faktu, iż spostrzeżenia T. Olczyka są wciąż inspirujące, bo nasza scena polityczna, mimo że otwarcie korzysta z inspiracji i wzorów amerykańskich, to jednak ze względu na bardziej konserwatywne podejście wyborców do kanałów komunikacji wydaje się jednak mieć kilka lat spóźnienia. Zobaczymy, jak na kolejne działania rodzimych polityków wpłyną obserwacje poczynione np. w czasie kampanii prezydenckiej w USA w 2016 r.

Opis T. Olczyka jest niezwykle przydatny także z innego powodu. Otóż uchwycony został moment, w którym po latach tabloidyzacji polityki (i polityków) okrzepł w Polsce model polityka-celebryty. Polityczni liderzy zaczęli zmieniać się w celebrytów wcześniej, jednakże status ów ugruntował się, objawił w dojrzałej formie właśnie w okresie badanym przez Olczyka ${ }^{6}$. Moim zdaniem przełomowym momentem tego procesu było utworzenie kanału TVN24, który emitując przez całą dobę wiadomości, sam skazał się na infotainment.

Potrzeba utrzymania telewidzów przed odbiornikami spowodowała, że rozpoczęto kreowanie własnych faktów, sensacji, konfliktów i emocji. Stworzono przestrzeń idealnie dopasowaną do potrzeb polityka-celebryty. Symbolicznym zaakceptowaniem istnienia takiego wzorca postaci (archetypu?) było włączenie w 2010 roku polityków do rankingu najcenniejszych gwiazd polskiego show-biznesu, przygotowywanego przez polską redakcję „Forbesa”. Ranking ów powstawał na podstawie dostarczonych przez agencje reklamowe informacji, ile byłyby one skłonne zapłacić za udział polskiego celebryty w przygotowywanej przez siebie kampanii ${ }^{7}$. Towarzysząca rankingowi wycena (w złotych) pozwalała dowiedzieć się, kto w danym momencie uznawany był za najbardziej zyskownego

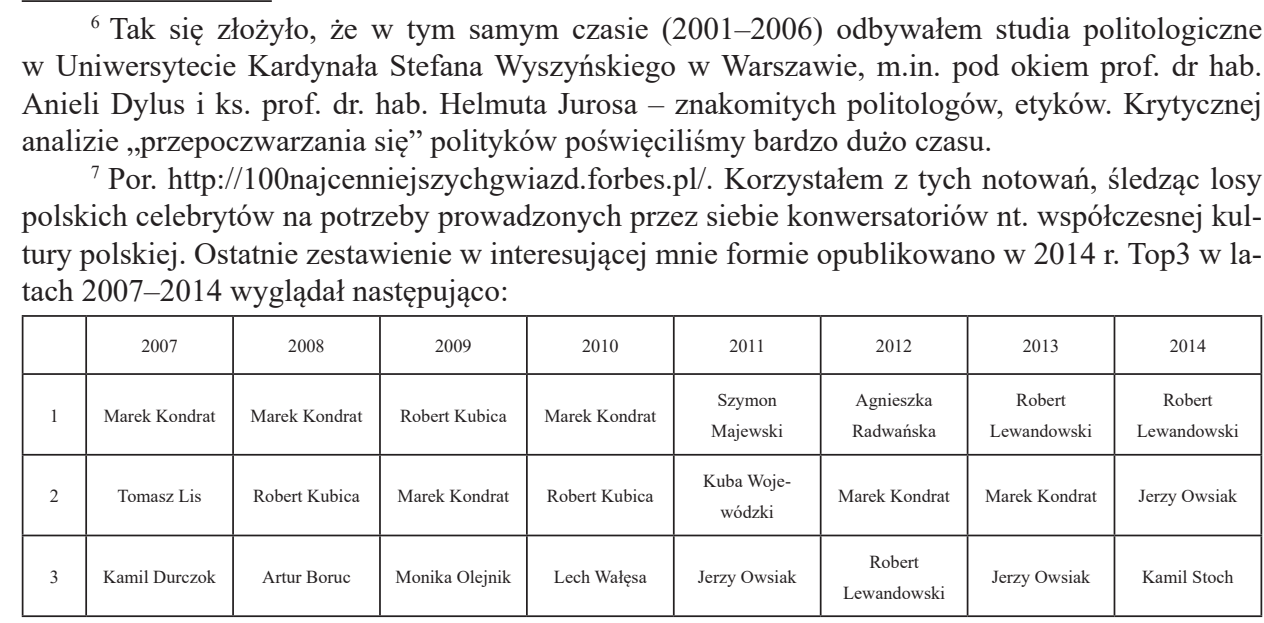


celebrytę. We wspomnianym już 2010 roku na listę trafili (podaję tylko pierwszą dziesiątkę): Lech Wałęsa (3. miejsce), Leszek Balcerowicz (4. miejsce), Donald Tusk (5. miejsce). Niestety, w kolejnych latach i rankingach zrezygnowano z polityków, co nie zmienia faktu, że ludzie związani z tzw. światem polityki z list nie wypadli. Od samego początku obecni byli w zestawieniach „Forbesa” dziennikarze: Monika Olejnik, Tomasz i Hanna Lisowie, Kamil Durczok, Justyna Pochanke, Jacek Żakowski i inni.

W mojej pracy nauczyciela jpjo, aka-fana (m.in. Jenkins 2006) zajmującego się kulturą bliską ciału (Jenkins, McPherson, Shattuc 2008), polszczyzna polityczna zajmuje ważne miejsce. Nie tylko dlatego, że jestem z wykształcenia (także) politologiem i za konieczne uważam objaśnianie cudzoziemskim podopiecznym mechanizmów zawiadujących sceną polityczną i państwem, a także większości zachowań polityków próbujących funkcjonować we współczesnej, dynamicznej pod względem kulturowym rzeczywistości. Również dlatego, że wiele moich ulubionych tematów (z perspektywy fana), badanych z perspektywy kulturoznawstwa glottodydaktycznego, istnieje w swoistym „sosie”, składającym się z przedziwnej mieszanki historyczno-politycznej, okraszonej popkulturowymi i rozrywkowymi elementami. Współczesnej kultury miejskiej, w moim przypadku warszawskiej, nie można zrozumieć bez analizy m.in. doświadczenia Powstania Warszawskiego, (sub)kultury kibicowskiej, (sub)kultury hiphopowej, wraz z towarzyszącymi im modą i językiem (slangiem). Wszystkie wymienione elementy należy badać w odniesieniu do wymienionych wyżej paradygmatów, porządkujących polskie dzieje i kulturę. A u podstaw takich rozważań i tak leży pytanie, na które próbujemy sobie odpowiedzieć od dekad: gdzie przebiega granica między nacjonalizmem a patriotyzmem?

\section{BIBLIOGRAFIA}

Bralczyk J., 2009, Przedmowa, w: R. Zimny, P. Nowak, Słownik polszczyzny politycznej po roku 1989, Warszawa, s. 5-6.

Burszta, W. J., 2009, W objęciach postkultury politycznej, w: T. Olczyk, Politrozrywka i popperswazja. Reklama telewizyjna w polskich kampaniach wyborczych XXI wieku, Warszawa, s. 11-18.

Czapliński P., 2009, Polska do wymiany. Późna nowoczesność i nasze wielkie narracje, Warszawa.

Giddens A., 2001, Nowoczesność i tożsamość. „Ja” i społeczeństwo w epoce późnej nowoczesności, przeł. A. Szulżycka, Warszawa.

Grossman E., 2010, Blaski i cienie globalizacji, czyli problemy polonistyki w badaniach komparatystycznych. Przyczynek do dalszych badań, w: R. Nycz, W. Miodunka, T. Kunz (red.), Polonistyka bez granic. Tom 2: Glottodydaktyka polonistyczna - wspótczesny język polski - językowy obraz świata, Kraków, s. 489-502.

Jenkins H., 2006, Introduction: Confessions of an Aca/Fan, w: Jenkins H., Fans, Bloggers, and Gamers. Exploring Participatory Culture, New York-London, s. 1-6. 
Jenkins H., McPherson T., Shattuc J., 2008, Kultura bliska ciału, przeł. M. Bernatowicz, M. Filiciak, „Kultura Popularna”, nr 1, s. 109-132.

Kajak P., 2010, ,O polityce po polsku” - treści politologiczne na zajęciach JPJO, „Acta Universitatis Lodziensis - Kształcenie Polonistyczne Cudzoziemców", nr 17, s. 137-144.

Olczyk T., 2009, Politrozrywka i popperswazja. Reklama telewizyjna w polskich kampaniach wyborczych XXI wieku, Warszawa.

Sztompka P., 2000, Trauma wielkiej zmiany. Społeczne koszty transformacji, Warszawa.

Zimny R., Nowak P., 2009, Stownik polszczyzny politycznej po roku 1989, Warszawa.

\section{Piotr Kajak}

\section{POP-HISTORY, POP-POLITICS, AND POLI-ENTERTAINMENT AS A PART OF HUMANITIES' TRAINING FOR FOREIGNERS}

Keywords: cultural studies in SLA/FLA, culture pedagogy, political sciences, Polish language in political context

Summary. Teaching Polish language and culture to foreigners, we attempt to prepare our learners to the possibly most comfortable life in new culture. We explain, among others, several historical and political topics, which take part in building our national identity. These elements are present in the Polish discourse and Polish cultural paradigms as myths and imaginations, surrounded by meanings and interpretations. This article consists of several thoughts of an experienced teacher who builds a brand of Poland through the instruction blending historical and political elements in the pop-cultural context. 